\title{
Biotransformations of HBCDs by Rhodococcus Strain Stu-38 and Identification of Transformation Products
}

\section{Fei Yu}

Shantou University

Wenqi Luo

Shantou University

Yuyang Li

Shantou University

Shanshan Meng

Shantou University

Xianbin Lin

Shantou University

Lele Li

Shantou University

Xueying Ye

Shantou University

Hui Wang

Shantou University

Tao Peng

Shantou University

Tongwang Huang

Shantou University

Zhong Hu ( $\nabla$ hzh@stu.edu.cn )

Shantou University

\section{Research Article}

Keywords: HBCDs, biotransformation, Rhodococcus, GC-MS

Posted Date: August 2nd, 2021

DOI: https://doi.org/10.21203/rs.3.rs-730122/v1 
License: (c) (i) This work is licensed under a Creative Commons Attribution 4.0 International License. Read Full License 


\section{Abstract}

1, 2, 5, 6, 9, 10-Hexabromocyclododecanes (HBCDs) are new brominated flame retardants causing serious environmental pollution. Dozens of degradative bacteria have been found with capacity to transform HBCDs. In the present study, an aerobic functional bacterium Rhodococcus strain stu-38 was isolated from enriched culture of mangrove sediment using HBCDs as carbon source. This strain could

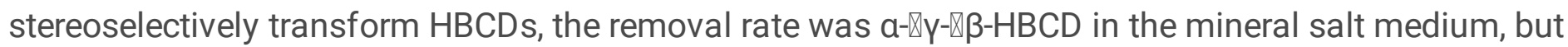
was $\beta$-『a- and $\gamma$-HBCD in the growth medium, and it selectively transformed $\gamma-H B C D$ in the seawater. Transformation rate of strain stu-38 was lower than other functional strains, however, seven potential debrominated products of HBCDs were identified by using GC-MS. These debrominated products, included dibromocyclododecadiene, bromocyclododecadienol and bromocyclododecatriene were formed through reductive debromination, hydrolytic debromination and dehydrobromination. Overall, Rhodococcus sp. stu-38 diastereoisomer-specifically transformed HBCDs to various debrominated products in the different cultural media, which highlighted the complicated stereoselective biotransformation of HBCDs.

\section{Introduction}

Hexabromocyclododecanes (HBCDs) are a new type of additive brominated flame retardants (BFRs) applied in extruded (XPS) and expanded (EPS) polystyrene foams. HBCDs are used to improve the flammability resistance or chemically bound to synthetic matrices such as plastics, textiles, electronic circuitry and other materials (Koch et al. 2015). HBCDs released from industry and waste products can infiltrate various ecosystems, leads to serious contamination (Cao et al. 2018). The first detection of environmental HBCDs was in fish and sediment samples from the river Viskan in Sweden, 1995 (Sellström et al. 1998). Since then, they have been found in various environmental media (Cao et al. 2018), even in the human body (Lu et al. 2018; Roosens et al. 2009). Since HBCDs were recalcitrant to degradation and could lead to neurotoxicity (Mariussen and Fonnum et al. 2003), disruption of the inflammatory response in the immune cells (Yasmin and Whalen et al. 2018) and the bronchial epithelial cells (Koike et al. 2016), they had been listed in Annex A of the Stockholm Convention on Persistent Organic Pollutants (POPs) in May 2013.

Over three tons of HBCDs were released into the environment in Europe each year (Koch et al. 2015). The environmental distribution of HBCDs is mainly in the soil and sediment (Cao et al. 2018; Zhang et al. 2018b), which benefits for biodegradation. Biotransformation of HBCDs has been observed in the sludge, soil and sediment. Half-lives of HBCDs in the environment varying from days to months (Davis et al. 2005, 2006; Gerecke et al. 2006; Stiborova et al. 2015). Both biotic and abiotic transformation contribute to removal of HBCDs while the biological activity can greatly enhance HBCDs transformation in the environment (Davis et al. 2006; Gerecke et al. 2006; Morris et al. 2004; Stiborova et al. 2015).

Numbers of isolated bacterial strains and enzymes have been found to transform HBCDs effectively. Bacillus sp. HBCD-sjtu could consume $90 \%$ of $321.0 \mu \mathrm{g} / \mathrm{mL}$ HBCDs in 4 days (Shah et al. 2018; Shah et 
al. 2019). Pseudomonas aeruginosa HS9 could degrade $69 \%$ HBCDs in four days and had been used for remediation test in plant soil (Huang et al. 2019). Anaerobic dehalorespiring strain Dehalobium chlorocoercia DF-1 was added to the sediment to remove -HBCD (Demirtepe and Imamoglu et al. 2019). $\mathrm{LinB}$, an hexachlorocyclohexanes ( $\mathrm{HCHs}$ ) haloalkane dehalogenase, converts $\mathrm{HBCD}$ s via hydrolytic debromination; LinA2, a HCHs dehydrochlorinase, converts HBCDs through HBr-elimination (Yu et al. 2021).

Three main diastereisomers of HBCDs in commercial products and environmental materials are $\alpha-, \beta$ - and $\mathrm{Y}$-HBCD. Bacterial debromination of HBCDs are generally diastereoisomer-specific (Yu et al. 2021). Sphingobium chinhatense IP26 could transform $27,20,78,63,39$ and $41 \%$ of $(-) a-,(+) a-,(-) \beta-$, $(+) \beta-,(-) \gamma^{-}$and $(+) y-H B C D s$ at $1.0 \mu \mathrm{g} / \mathrm{mL}$ in 6 days (Heeb et al. 2017). The degradation rates of $\alpha-, \beta-, \gamma^{-}$ HBCD by Pseudomonas sp. GJY were with small differences $(85.38,82.64$ and $75.50 \%$ in 8 days, respectively), but this strain could transform three diastereoisomers to different products (Geng et al. 2019). Strain HB01 selectively debrominated $81 \%$ Y-HBCD at a high concentration of $642.0 \mu \mathrm{g} / \mathrm{mL}$ in 5 days (Yamada et al. 2009). Anaerobic strain Dehalococcoides mccartyi 195 stereoselectively transformed HBCDs, and the transformation rate of three diastereoisomers followed the order of $a-H B C D>\beta-H B C D>\gamma^{-}$ HBCD (Zhong et al. 2018). Diastereoisomer selection had been observed in dehalogenases too. (-)a-, (+) $\beta-$-, and $(+)$ Y-HBCDs were transformed faster by LinB than their enantiomers, and LinA2 selectively catalyzed the transformation of $\beta$-HBCDs (Heeb et al. 2012; 2013; 2014; 2015). It may conclude that the diastereoisomer-specific transformation of HBCDs are result from structurally selection of dehalogenase on the substrates (Heeb et al. 2021; Heeb et al. 2012; Heeb et al. 2013; Suar et al. 2005). However, the debromination behavior of bacterial strain can be different from that of their dehalogenases. For example, though S. chinhatense IP26 has genes encoding LinA and LinB, this strain transforms HBCDs through hydrolytic pathway (Heeb et al. 2012, 2017, 2021), which may suggest that the transformation pathway is selectable for functional bacteria.

Moreover, the long half-lives of HBCDs (Davis et al. 2005, 2006) along with the absence of known degradative bacteria in the contaminated material (Stiborova et al. 2015) indicated that the efficient degradative bacteria might not contribute to degradation of HBCDs in situ. Dozens of lower effective strains were reported but uncharacterized in the literature (Chang et al. 2020; Yamada et al. 2009), leaving the role of strains with lower efficiency were unclear in the remediation.

Present research investigated the HBCDs transformation by Rhodococcus sp. stu-38 in the different materials including mineral salt medium, seawater and the nutrient seawater. In three media, different diastereoisomer-specific transformation trends of HBCDs by this strain were found yielding different debrominated products identified by using GC-MS. Therefore, the results obtained here provided the primary knowledge about the diastereoisomer-specific transformation patterns of a functional strain in various environmental materials, and might contribute to the bioremediation of HBCDs contamination.

\section{Materials And Methods}




\section{Chemicals and media}

The HBCDs used in this study was a composite of a commercial sample supplied by Adamas-beta (Adamas Reagent Co., Ltd. Switzerland). The composition is about $17.7 \%: 10.6 \%: 71.7 \%$ for $\alpha-, \beta$ - and $\gamma^{-}$ $\mathrm{HBCD}$. Mineral salt medium (MSM) contained $1.0 \mathrm{~g} / \mathrm{L}\left(\mathrm{NH}_{4}\right)_{2} \mathrm{SO}_{4}, 0.8 \mathrm{~g} / \mathrm{L} \mathrm{Na}_{2} \mathrm{HPO}_{4}, 0.2 \mathrm{~g} / \mathrm{L} \mathrm{KH}_{2} \mathrm{PO}_{4}, 0.2$

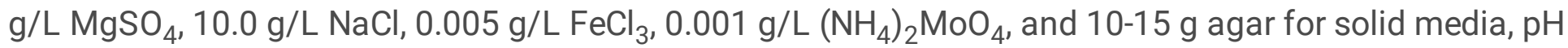
7.0. For the liquid media containing HBCDs, HBCDs were dissolved in dichloromethane, injected into flasks. Dichloromethane was volatilized before injection of liquid media. Solid MSM was prepared with $1.5 \mathrm{mg} \mathrm{HBCDs}$ on the surface.

Seawater was obtained from the offshore area of Shantou, China. Seawater media was filtered through $0.45 \mu \mathrm{m}$ and sterilized. Seawater-LB medium was composed of seawater, $10 \mathrm{~g} / \mathrm{L}$ peptone, $5 \mathrm{~g} / \mathrm{L}$ yeast extract powder, $\mathrm{pH}$ 7.2-7.5. $100 \mu \mathrm{g} \mathrm{HBCDs}$ were dissolved in dichloromethane, injected into each $50 \mathrm{~mL}$ centrifugal tube. Dichloromethane was volatilized before addition of media and bacteria.

\section{Strain isolation and identification}

Mangrove sediment was collected from Zhanjiang, China. Sediment was mixed with $100 \mathrm{~mL}$ of MSM media using $30.0 \mathrm{mg} / \mathrm{L} \mathrm{HBCDs}$ as the sole carbon source to enrich functional bacteria. The mixture was cultured at room temperature around $25^{\circ} \mathrm{C}, 150 \mathrm{r} / \mathrm{min}$. After 30 days, $2 \mathrm{~mL}$ of mixture was transferred to a new flask with $100 \mathrm{~mL} \mathrm{MSM}$ and $30.0 \mathrm{mg} / \mathrm{L} \mathrm{HBCDs}$. In the fifth transfer, the culture was used for isolation on solid media contain HBCDs. Six strains were obtained and named 38-43 in order. The 16S rRNA gene of strains was amplified using the universal primers $27 \mathrm{~F}$ and $1492 \mathrm{R}$, and sequenced by BGI (Guangzhou, China). The 16S rRNA sequence was aligned using Nucleotide Blast on the NCBI web (https://blast.ncbi.nlm.nih.gov/Blast.cgi). The phylogenetic tree was generated using the neighbor-joining method with MEGA 5.0. Strain 38, renamed stu-38 was used for further research.

\section{Batch experiments}

Five groups were set up. In the freshwater group (FW), bacteria were cultured in the seawater-LB media for two days. Cells were harvested by centrifuge at $6000 \mathrm{rpm} / \mathrm{min}$, resuspended with $1 \mathrm{~mL} \mathrm{MSM}$. Then the cells were inoculated to a $50 \mathrm{~mL}$ tube containing $100 \mu \mathrm{g} \mathrm{HBCDs}$ and $5 \mathrm{~mL} \mathrm{MSM}$. The final concentration of HBCDs was $16.7 \mu \mathrm{g} / \mathrm{mL}$. Controls (FW-C) were without addition of cells. In the other two groups, seawater and seawater-LB were used to replace MSM, designed as SW and SWLB which were containing cells of strain stu-38. SWLB-C and SW-C were controls without cells. All groups were cultured at room temperature $\left(25-30^{\circ} \mathrm{C}\right), 150 \mathrm{rpm} / \mathrm{min}$. Each group was triplicate. The residual HBCDs in the FW and FW-C were determined after two months. The residual HBCDs in the SWLB, SWLB-C, SW and SW-C were determined at one month.

\section{Determination of HBCDs residues and identification of debrominated products}


To analyze the residues and debrominated products of HBCDs, the cultures were frozen and dried, and extracted by $15 \mathrm{~mL}$ of $\mathrm{n}$-hexane, dichloromethane and acetone in the proportion of 1:1:1. The extracts were dried and dissolved in the methanol, determined by Liquid Chromatograph Mass Spectrometer (LCMS, Thermo TSQ-Endura, USA) equipped with a dual-mode discrete-dynode detector and a Hypersil GOLD $1.9 \mu$ column $(50 \times 2.1 \mathrm{~mm})$. Solvent A (methanol: acetonitrile $=80 \%: 20 \%)$ and solvent $\mathrm{B}(10 \mathrm{mmol} / \mathrm{L}$ $\mathrm{NH}_{4} \mathrm{Ac}$ ) were used as mobile phase. The mobile phase composition started with solvent $\mathrm{A}: \mathrm{B}$ at $50 \%: 50 \%$, then to $90 \%$ : $10 \%$ in 9 minutes, ended up with $100 \%$ solvent $A$ in 13 minutes (Morris et al. 2004). The transformation of HBCD was followed by monitoring the HBCD molecular precursor ion $(\mathrm{m} / \mathrm{z}=640.6$ $\mathrm{amu}$ ) and its fragment ions ( $\mathrm{m} / \mathrm{z}=79.1,81.1$ and $560.5 \mathrm{amu})$. Concentrations of HBCD were quantified based on the HBCD molecular ion ( $\mathrm{m} / \mathrm{z}=81.1 \mathrm{amu}$ ) (Davis et al. 2005). The recoveries of HBCDs in the MSM, SW and SWLB were in the range of $111.1-122.5 \%, 64.0-70.7 \%$ and $140-146 \%$, respectively. The transformation efficiency $\eta$ was defined as

$\eta=\left(C_{0}-C_{t}\right) / C_{0} \times 100 \%$,

where $\mathrm{C}_{0}$ was the concentration of control at time $\mathrm{t}$ in the $\mathrm{FW}$ or initial concentration of substrate in other groups, $\mu \mathrm{g} / \mathrm{L} ; C_{t}$ was the concentration of HBCD at time $t, \mu \mathrm{g} / \mathrm{L}$.

After determination, the extracts were dried and dissolved in the mixture of n-hexane, dichloromethane and acetone, analyzed by Gas Chromatography/ Mass Spectrometer (GC-MS, QP-2010ULTRA model, Shimadzu, Japan) equipped with a HP-5ms Ultra Inert Capillary Column (30 m×0.25 mm×0.25 $\mu \mathrm{m}$ film thickness). The procedures were $80^{\circ} \mathrm{C}$ for $1 \mathrm{~min}$, then increase to $250{ }^{\circ} \mathrm{C}$ in $13 \mathrm{~min}$ by $10{ }^{\circ} \mathrm{C} / \mathrm{min}$, and end up with $250^{\circ} \mathrm{Cfor} 10 \mathrm{~min}$. Full scan of molecules in the range of $30-700 \mathrm{~m} / \mathrm{z}$ was performed in select ion monitoring (SIM) mode to detect possible brominated degradation products (Davis et al. 2005; Zhong et al. 2018). HBCDs dissolved in the acetone and placed in the room temperature for 48 hours to harvest debrominated products (Zhong et al. 2010) were used as the positive control for identification.

Table 1 transformation products identified by GC-MS 


\begin{tabular}{|c|c|c|c|c|c|}
\hline & proposed products & structure & $\mathrm{m} / \mathrm{z}$ & retention time & culture \\
\hline \multirow{2}{*}{1} & $\mathrm{C}_{12} \mathrm{H}_{17} \mathrm{Br}$ & & \multirow{2}{*}{241} & 7.945 & MSM \\
\hline & bromocyclododecatriene & & & 10.230 & SW-LB \\
\hline \multirow{2}{*}{2} & $\mathrm{C}_{12} \mathrm{H}_{18} \mathrm{BrOH}$ & & \multirow{2}{*}{259} & \multirow{2}{*}{8.355} & \multirow{2}{*}{ MSM } \\
\hline & bromocyclododecadienol & & & & \\
\hline \multirow{3}{*}{3} & $\mathrm{C}_{1} \mathrm{H}_{10} \mathrm{Rm}$ & & \multirow{3}{*}{322} & 11.280 & MSM \\
\hline & 10118012 & & & 14.065 & SW \\
\hline & & & & 13.085 & SW-LB \\
\hline \multirow{2}{*}{4} & $\mathrm{C}_{12} \mathrm{H}_{19} \mathrm{OH}$ & & \multirow{2}{*}{180} & 6.115 & SW \\
\hline & cyclododecadienol & & & 7.280 & SW-LB \\
\hline \multirow{3}{*}{5} & $\mathrm{C}_{12} \mathrm{H}_{18} \mathrm{O}$ & & \multirow{3}{*}{178} & \multirow{3}{*}{6.845} & \multirow{3}{*}{ SW } \\
\hline & 1,2-epoxy- & & & & \\
\hline & 5,9-cyclododecadiene & & & & \\
\hline \multirow{2}{*}{6} & $\mathrm{C}_{12} \mathrm{H}_{18}(\mathrm{OH})_{2}$ & & \multirow{2}{*}{196} & \multirow{2}{*}{7.395} & \multirow{2}{*}{ SW } \\
\hline & cyclododecadiendiol & & & & \\
\hline \multirow{2}{*}{7} & $\mathrm{C}_{12} \mathrm{H}_{16} \mathrm{BrOH}$ & & \multirow{2}{*}{257} & \multirow{2}{*}{10.910} & \multirow{2}{*}{ SW-LB } \\
\hline & bromocyclododecatrienol & & & & \\
\hline
\end{tabular}

\section{Results}

\section{Isolation and identification of bacteria}

Six of bacterial strains grew on MSM containing HBCDs were obtained. The colony of strain 38 turned slight red on solid SWLB medium after several days of culture (Fig. 1a). Its 16S rRNA gene sequence displayed 99\% identity with Rhodococcus strains through Nucleotide Blast analysis on the NCBI website. The GenBank accession number of its 16S rRNA was MT815909. The isolated strain 38 was renamed Rhodococcus sp. stu-38. Strain 39 to 43 were identified as Marinobacter, Nitratireductor, Brucella, Sinomonas and Ochrobactrum in order, as displayed in the Fig. 1.

Transformation of HBCDs by Rhodococcus sp. stu-38 
The transformation rates of HBCD s by isolates in the FW were determined. Strain Rhodococcus sp. stu-38 showed better removal ability than others. As was shown in Fig. 2. 37\% a-HBCD and 24\% y-HBCD were removed in comparison with control in two months. And the lowest removal rate was on $\beta$-HBCD. Strain Marinobacter slightly transformed HBCDs. Nitratireductor, Brucella, Sinomonas, Ochrobactrum did not showed transformation ability. Therefore, strain Rhodococcus sp. stu-38 were used for further research.

The residual HBCDs in the SW were determined in one month (Fig. 3). At the end of incubation, $42 \%$ and $36 \%$ of $Y$-HBCD were removed in the SW and SW-C, respectively. Only about $6 \%$ loss of $Y-H B C D$ was related to strain stu-38. However, the decrease of $a-$ and $\beta-H B C D$ were hardly observed. $33 \%, 51 \%$ and $34 \%$ of $\alpha-, \beta$ - and $\gamma$-HBCD were removed in SWLB in one month (Fig. 4). In the SWLB-C, about $15 \%, 19 \%$, and $16 \%$ of $\alpha-, \beta$ - and $\gamma$-HBCD were removed abiotically in one month. Removal of $18 \%, 32 \%, 18 \%$ of $\alpha-\beta$ - and $\gamma$-HBCD were related to strain stu-38. In total, $39 \%$ of HBCDs in the SWLB was removed in four weeks, higher than $17 \%$ in the SWLB-C.

\section{Identification of the debrominated products}

GC-MS was used to identify the debrominated products of HBCDs since the $\mathrm{m} / \mathrm{z}$ of fragment ions were clear (Fig. S1). In the acetone, HBCDs can be chemically debrominated to tribromocyclododecadiene $\left(\mathrm{C}_{12} \mathrm{H}_{15} \mathrm{Br}_{3}\right)$ and dibromocyclododecadiene $\left(\mathrm{C}_{12} \mathrm{H}_{14} \mathrm{Br}_{2}\right)$ which were used as positive controls (Fig. S2 and S6). The character ions were $\mathrm{C}_{12} \mathrm{H}_{15} \mathrm{Br}_{3}, \mathrm{~m} / \mathrm{z}=400.0 ; \mathrm{C}_{12} \mathrm{H}_{14} \mathrm{Br}_{2}, \mathrm{~m} / \mathrm{z}=319.1 ; \mathrm{C}_{12} \mathrm{H}_{13} \mathrm{Br}, \mathrm{m} / \mathrm{z}=238.2 ; \mathrm{C}_{12} \mathrm{H}_{12}$, $\mathrm{m} / \mathrm{z}=157.3 ; \mathrm{C}_{6} \mathrm{H}_{7}, \mathrm{~m} / \mathrm{z}=79$. Together, seven debrominated products with carbon frame of HBCDs were identified (table 1). There were two lower brominated alkenes, including dibromocyclododecadiene, bromocyclododecatriene; two lower brominated alkenols, including bromocyclododecadienol and bromocyclododecatrienol; the carbon skeleton of HBCDs, cyclododecatriene; two hydroxylated cyclododecatrienes, including cyclododecadienol and cyclododecadiendiol; one oxidized cyclododecatriene, 1,2-epoxy-5,9-cyclododecadiene. These debrominated products were present at low level (Fig. S6-S9), and were absent in the FW-C, SW-C, SWLB-C and the HBCDs standard solution.

\section{Discussion}

\section{Transformation of HBCDs by Rhodococcus strain stu-38}

In the present research, six bacterial strains grew on MSM containing HBCDs were isolated. Strain Rhodococcus sp. stu-38 showed better transformation ability than the others. Stu-38 could not use HBCDs as the sole carbon source and might survive the oligotrophic HBCDs-containing media by living on $\mathrm{CO}_{2}$ (Feisthauer et al. 2008; Ohhata et al. 2007; Yano et al. 2015). Some Rhodococcus strains had been found with dehalogenation capacity, for example, strains 1CP, JT-3 and EK2 could transform various organohalides (Khosrowabadi and Huyop et al. 2014; Roth et al. 2013; Zhang et al. 2018a). This is the first study demonstrated the capacity of Rhodococcus strain to convert HBCDs.

The HBCD semoval ability of strain stu-38 was lower than functional strains from other research. For example, Bacillus sp. HBCD-sjtu was reported to consume $90 \%$ HBCDs at $321.0 \mu \mathrm{g} / \mathrm{mL}$ in four days (Shah 
et al. 2018; Shah et al. 2019). Sphingobium chinhatense IP26 could transform $78 \%$ and $63 \%$ of (-) $\beta$ - and (+) $\beta$-HBCDs from initial concentration of $1.0 \mu \mathrm{g} / \mathrm{mL}$ in six days (Heeb et al. 2017). The low efficient transformation ability of stu-38 could be a heritage of converting natural organohalides in situ (Verma et al. 2014; Kaster et al. 2014; Yu et al. 2021). The sediment applied for enrichment culture was rarely contaminated HBCDs (unpublished data), which might not be a selective pressure for indigenous bacteria.

Rhodococcus sp. stu-38 selectively removed a-HBCD and $\mathrm{y}-\mathrm{HBCD}$ in the FW. The selective transformation by strain stu-38 was also found in SWLB where $33 \%, 51 \%$ and $34 \%$ of $\alpha-, \beta$ - and $\gamma-H B C D$ were removed. $\beta$ HBCD was rarely transformed by strain stu-38 in the FW and SW (Fig. 2 and 3). But in SWLB, strain stu-38 could removed $32 \% \beta-H B C D$, and showed better transforming ability on $\alpha-$ and $\gamma-H B C D$ (Fig. 4).

Biotransformation rates of a functional strain in different media were not well studied. $P$. aeruginosa HS9 could degrade $69 \%$ HBCDs in the MSM in 14 days, but removed $88 \%$ HBCDs in the plant soil (Huang et al. 2019). It indicated that the different factor in growing environment of bacteria could affect their transformation ability, in corresponding to biodehalogenation of other organic halogenated compounds (Wang et al. 2015). Diastereoisomers-specific biotransformation of HBCD was also observed in other functional strains. S. chinhatense IP26 could transform $27,20,78,63,39$ and $41 \%$ of $(-) a-,(+) \alpha-,(-) \beta-$, $(+) \beta-,(-) \gamma-$ and $(+) y-H B C D s$ at $1.0 \mu \mathrm{g} / \mathrm{mL}$ in 6 days (Heeb et al. 2017). Achromobacter sp. HBCD-1 (Peng et al. 2015), D. mccartyi 195 (Zhong et al. 2018), Pseudomonas sp. GJY (Geng et al. 2019) were more effective on debromination of a-HBCD. Pseudomonas sp. strain HB01 (Yamada et al. 2009) selectively transformed $81 \% \mathrm{Y}-\mathrm{HBCD}$ in five days. The stereoselection on transforming HBCDs was result from the fitness of substrates to the active site of enzyme as revealed by the investigation of dehalogenases LinB, LinA1, LinATM and LinA2 (Heeb et al. 2021; Heeb et al. 2012; Heeb et al. 2013; Suar et al. 2005). As indicated in this study, bacterial diastereoisomer-specificity could also affect by the cultural media.

\section{$R$. sp. stu-38 facilitated the abiotic transformation of HBCDs}

Biotransformation half-lives of HBCDs are varying from a few days to over 100 days in the sludge, soil and sediment (Yu et al. 2021). Present study shew that abiotic transformation of HBCDs had a major contribution in the seawater media, which was corresponding to previous reports that abiotic loss was a large contribution in transformation of HBCDs in the aquatic sediment and active sludge (Davis et al. 2005 , 2006). The removal rates of SW and SWLB were higher than SW-C and SWLB-C, indicated that the presence of strain stu-38 could facilitate the removal of HBCDs, which was corresponding to other research (Huang et al. 2019). Chemical and physical factors can lead to abiotic transformation of HBCDs, for example, FeS, nanoscale zero-valent aluminum, sulfidated nanoscale zerovalent iron, and ultraviolet light (Franke et al. 2017; Palau et al. 2017; Yu et al. 2015). Abiotic transformation of HBCDs could have been mediated by chemicals since the cultures were placed in the dark environment.

The augmentation of glucose increased bacterial diversity and improved the removal of HBCDs in the suspension of planted soil (Le et al. 2017). Biostimulation of carbon source could improve the removal of $\mathrm{Y}$-HBCD in the sediment (Demirtepe and Imamoglu et al. 2019). Present research shew that the addition 
of nutrition enhanced the removal of HBCDs by stu-38 because bacteria might maintain high activity in the nutrient media. It suggested the augmentation of carbon source as a strategy to improve bioremediation in the contaminated sites. This was different from previous research using pure bacterial strain to transform 3-chlorobenzoate (Chobchuenchom et al. 1996).

\section{The formation of the debrominated products}

HBCDs could be chemically debrominated to tribromocyclododecadiene and dibromocyclododecadiene in the acetone (Fig. S2 and S6) (Zhong et al. 2010). At the same retention time, the intensity of tribromocyclododecadiene $(\mathrm{m} / \mathrm{z}=401,321,241$ and 159) and dibromocyclododecadiene $(\mathrm{m} / \mathrm{z}=321,241$ and 159) were much smaller in the SW than in the acetone (Fig. S2). It was because of the high levels of chemicals from seawater and cells, which could result in the difficulties for the identification of pentaand tetra- brominated products and the detection of a- and $\beta$-HBCD (Fig. S1, S7-S9). Moreover, the low transformation efficiency of strain stu-38 leaded to the debrominated products presented at low concentration and weak intensity (Fig. S3-S5, S7-S9).

By using GC-MS, seven biodebrominated products were identified relying on mass spectra of GC-MS (Table 1; Fig. S3-S5, S6-S9). But the accurate identification and further determination were difficult because the limit of standards. Based on the debrominated products observed, the possible transformation pathways of HBCD s by strain stu-38 in the FW, SW and SWLB were proposed (Fig. 5).

The debromination pathways of HBCDs include HBr-elimination (dehydrobromination), $\mathrm{HBr}$ dihaloelimination and hydrolytic debromination (Ang et al. 2018; Yu et al. 2015). HBr-elimination of $\mathrm{HBCD}$ yields lower brominated compounds with an $\mathrm{HBr}$ removed to form a carbon-carbon double bond (Kunze et al. 2017). Dihaloelimination involves electron transfer in which HBCDs serve as electron acceptor. Hydrolytic debromination yields lower brominated alkanol or alkenol. These debromination pathways were all observed in the transformation of HBCDs by $R$. sp. stu-38 (Fig. 5). As the toxicity of debrominated products were unknown, it was unclear if the toxicity of debrominated products resulted in the low efficiency of $R$. sp. stu-38 (Heeb et al. 2017; Lal et al. 2010; van Hylckama Vlieg et al. 2000).

Dibromocyclododecadiene, formed through HBr-dihaloelimination, were found in FW, SW and SWLB (Fig. 5). Full debromination via dihaloelimination and the cleavage of cyclododecatriene was not found in this research. The ring opening intermediate was observed in the study of strain GJY (Geng et al. 2019). Strain HS9 (Huang et al. 2019) and GJY (Geng et al. 2019) could convert HBCDs through both reductive and hydrolytic debromination yielding various intermediates. Stu-38 shew similar debromination patterns in the FW and SW, but the biotransformation of HBCDs in the SWLB was more complicated (Fig. 5, S5).

Anaerobic strains D. mccartyi 195 (Zhong et al. 2018) and A. sp. HBCD-1 (Peng et al. 2015), aerobic strains P. aeruginosa HS9 (Huang et al. 2019) and P. sp. GJY (Geng et al. 2019) could convert HBCDs through dihaloelimination. The oxygen-tolerant nonrespiratory reductive dehalogenase was also reported (Payne et al. 2015). However, genes encoding such enzymes were not annotated in the genome of stu-38 except several genes encoding haloalkane dehalogenase and haloacid dehalogenase (data not 
shown). Haloalkane dehalogenase LinB is known for converting HBCDs via hydrolytic debromination (Heeb et al. 2012). Therefore, further research needs to identify the functional dehalogenases in the $R$. sp. stu-38.

\section{Conclusion}

In summary, a new HBCDs-transforming bacteria Rhodococcus sp. stu-38 was identified in the present research. This strain selectively transformed HBCDs diastereoisomers in the mineral salt medium, seawater and nutrient seawater. Seven debrominated products were identified by using GC-MS. The formation of debrominated products were partially depended on the culture media. Together, this study demonstrated a functional Rhodococcus originated from mangrove sediment which could diastereoisomer-specifically transform HBCDs depending on its living environment, which highlight the monitoring of various lower brominated products of contaminants during bioremediation.

\section{Declarations}

\section{Authors' contributions}

Wenqi Luo, Xianbin Lin, Shanshan Meng, Lele Li performed the serial diluting culture with HBCDs supplied as the sole carbon source. Fei Yu isolated the bacteria, performed the rest experiment and completed the manuscript. Yuyang Li analyzed the genomic sequence of bacteria. Xueying Ye, Tao Peng, Hui Wang, Tongwang Huang, Zhong Hu provided the directions. All authors read and approved the final manuscript.

\section{Competing Interest}

The authors declare that they have no known competing financial interests or personal relationships that could have appeared to influence the work reported in this paper.

\section{Acknowledgements}

This research was supported by the National Natural Science Foundation of China $(31870104,32070114$, 31770130 and 32000072).

\section{Ethical approval}

This article does not contain any studies with human participants or animals performed by any of the authors.

\section{References}

Ang TF, Maiangwa J, Salleh AB, Normi YM, Leow TC (2018) Dehalogenases: From Improved Performance to Potential Microbial Dehalogenation Applications. Molecules 
Cao X, Lu Y, Zhang Y, Khan K, Wang C, Baninla Y (2018) An overview of hexabromocyclododecane (HBCDs) in environmental media with focus on their potential risk and management in China. Environ Pollut 236:283-295. https://doi.org/10.1016/j.envpol.2018.01.040

Chang TH, Wang R, Peng YH, Chou TH, Li YJ, Shih YH (2020) Biodegradation of hexabromocyclododecane by Rhodopseudomonas palustris YSC3 strain: A free-living nitrogen-fixing bacterium isolated in Taiwan. Chemosphere 246:125621. https://doi.org/10.1016/j.chemosphere.2019.125621

Chobchuenchom W, Mongkolsuk S, Bhumiratana A (1996) Biodegradation of 3-chlorobenzoate by Pseudomonas putida 10.2. World J Microbiol Biotechnol 12: 607-

\section{4. https://doi.org/10.1007/BF00327723}

Davis JW, Gonsior S, Marty G, Ariano J (2005) The transformation of hexabromocyclododecane in aerobic and anaerobic soils and aquatic sediments. Water. Res 39:1075-

84. https://doi.org/10.1016/j.watres.2004.11.024

Davis JW, Gonsior SJ, Markham DA, Friederich U, Hunziker RW, Ariano JM (2006) Biodegradation and product identification of ${ }^{[14 C]}$ hexabromocyclododecane in wastewater sludge and freshwater aquatic sediment. Environ Sci Technol 40:5395-401. https://doi.org/10.1021/es060009m

Demirtepe H, Imamoglu I (2019) Biostimulation enhanced the biotic degradation of hexabromocyclododecane in sediments. J Soil Sediment 19:2859-2868. https://doi.org/10.1007/s11368019-02280-z

Feisthauer S, Wick LY, Kästner M, Kaschabek SR, Schlömann M, Richnow HH (2008) Differences of heterotrophic ${ }^{13} \mathrm{CO}_{2}$ assimilation by Pseudomonas knackmussii strain $\mathrm{B} 13$ and Rhodococcus opacus $1 \mathrm{CP}$ and potential impact on biomarker stable isotope probing. Environ Microbiol 10:1641-51. https://doi.org/10.1111/j.1462-2920.2008.01573.x

Franke S, Lihl C, Renpenning J, Elsner M, Nijenhuis I (2017) Triple-element compound-specific stable isotope analysis of 1,2-dichloroethane for characterization of the underlying dehalogenation reaction in two Dehalococcoides mccartyi strains. FEMS Microbiol Ecol 93. https://doi.org/10.1093/femsec/fix137

Geng J, Han M, Yang X, Li Y, Bartlam M, Wang Y (2019) Different biotransformation of three hexabromocyclododecane diastereoisomers by Pseudomonas sp. under aerobic conditions. Chem Eng J 374:870-879. https://doi.org/10.1016/j.cej.2019.05.232

Gerecke AC, Giger W, Hartmann PC, Heeb NV, Kohler H-PE, Schmid P, Zennegg M, Kohler $M(2006)$ Anaerobic degradation of brominated flame retardants in sewage sludge. Chemosphere 64:311317. https://doi.org/10.1016/j.chemosphere.2005.12.016 
Heeb NV, Grubelnik A, Geueke B, Kohler HE, Lienemann P (2017) Biotransformation of hexabromocyclododecanes with hexachlorocyclohexane-transforming Sphingobium chinhatense strain IP26. Chemosphere 182:491-500. https://doi.org/10.1016/j.chemosphere.2017.05.047

Heeb NV, Hubeli J, Fleischmann T, Lienemann P, Nayyar N, Lal R, Kohler HE (2021) Transformation of $\varepsilon$ HBCD with the Sphingobium Indicum enzymes LinA1, LinA2 and LinATM, a triple mutant of LinA2.

Chemosphere 267:129217. https://doi.org/10.1016/j.chemosphere.2020.129217

Heeb NV, Zindel D, Geueke B, Kohler HP, Lienemann P (2012) Biotransformation of Hexabromocyclododecanes (HBCDs) with LinB--an HCH-converting bacterial enzyme. Environ Sci Technol 46:6566-74. https://doi.org/10.1021/es2046487

Heeb NV, Zindel D, Graf H, Azara V, Schweizer WB, Geueke B, Kohler HP, Lienemann P (2013) Stereochemistry of LinB-catalyzed biotransformation of delta-HBCD to $1 R, 2 R, 5 S, 6 R, 9 R, 10 S-$ pentabromocyclododecanol. Chemosphere 90:1911-

9. https://doi.org/10.1016/j.chemosphere.2012.10.019

Heeb NV, Wyss SA, Geueke B, Fleischmann T, Kohler HE, Bernd Schweizer W, Moor H, Lienemann P (2015). Stereochemistry of enzymatic transformations of (+)beta- and (-)beta-HBCD with LinA2-a HCH-degrading bacterial enzyme of Sphingobium indicum B90A. Chemosphere 122:70-

78. https://doi.org/10.1016/j.chemosphere.2014.11.008

Heeb NV, Wyss SA, Geueke B, Fleischmann T, Kohler HE, Lienemann P (2014) LinA2, a HCH-converting bacterial enzyme that dehydrohalogenates HBCDs. Chemosphere 107:194-

202. https://doi.org/10.1016/j.chemosphere.2013.12.035

Huang L, Wang W, Shah SB, Hu H, Xu P, Tang H (2019) The HBCDs Biodegradation using a Pseudomonas Strain and Its Application in Soil Phytoremediation. J Hazard Mater

380:120833. https://doi.org/10.1016/j.jhazmat.2019.120833

Kaster AK, Mayer-Blackwell K, Pasarelli B, Spormann AM (2014) Single cell genomic study of Dehalococcoidetes species from deep-sea sediments of the Peruvian Margin. ISME J 8:183142. https://doi.org/10.1038/ismej.2014.24

Khosrowabadi E, Huyop FJBJ (2014) Screening and Characterization of Several 2,2-Dicholoropropionic Acid-Degrading Bacteria Isolated from Marine Sediment of Danga Bay and East Coast of Singapore Island. Bioremed J 18:20-27. https://doi.org/10.1080/10889868.2013.834868

Koch C, Schmidt-Kotters T, Rupp R, Sures B (2015) Review of hexabromocyclododecane (HBCD) with a focus on legislation and recent publications concerning toxicokinetics and -dynamics. Environ Pollut 199:26-34. https://doi.org/10.1016/j.envpol.2015.01.011 
Koike E, Yanagisawa R, Takano H (2016) Brominated flame retardants, hexabromocyclododecane and tetrabromobisphenol A, affect proinflammatory protein expression in human bronchial epithelial cells via disruption of intracellular signaling. Toxicol In Vitro 32:212-9. https://doi.org/10.1016/j.tiv.2015.12.013

Kunze C, Diekert G, Schubert T (2017) Subtle changes in the active site architecture untangled overlapping substrate ranges and mechanistic differences of two reductive dehalogenases. FEBS $\mathrm{J}$ 284:3520-3535. https://doi.org/10.1111/febs.14258

Lal R, Pandey G, Sharma P, Kumari K, Malhotra S, Pandey R, Raina V, Kohler HP, Holliger C, Jackson C, Oakeshott JG (2010) Biochemistry of microbial degradation of hexachlorocyclohexane and prospects for bioremediation. Microbiol. Mol Biol Rev 74:58-80. https://doi.org/10.1128/MMBR.00029-09

Le TT, Son MH, Nam IH, Yoon H, Kang YG, Chang YS (2017) Transformation of hexabromocyclododecane in contaminated soil in association with microbial diversity. J Hazard Mater 325:82-

89. https://doi.org/10.1016/j.jhazmat.2016.11.058

Lu S, Tan Z, Jiang Y, Wu D, Zhang J, Zhou J, Lin X (2018) Hexabromocyclododecanes in breast milk from residents in Shenzhen, China: Implications for infant exposure. Sci Total Environ 622-623:10901097. https://doi.org/10.1016/j.scitotenv.2017.11.277

Mariussen E, Fonnum F (2003) The effect of brominated flame retardants on neurotransmitter uptake into rat brain synaptosomes and vesicles. Neurochem Int 43:533-542. https://doi.org/10.1016/S01970186(03)00044-5

Morris S, Allchin CR, Zegers BN, Haftka JJ, Boon JP, Belpaire C, Leonards PE, Van Leeuwen SP, De Boer $J(2004)$ Distribution and fate of HBCD and TBBPA brominated flame retardants in North Sea estuaries and aquatic food webs. Environ Sci Technol 38:5497-504. https://doi.org/10.1021/es049640i

Ohhata N, Yoshida N, Egami H, Katsuragi T, Tani Y, Takagi H (2007) An extremely oligotrophic bacterium, Rhodococcus erythropolis N9T-4, isolated from crude oil. J Bacteriol 189:6824-

31. https://doi.org/10.1128/JB.00872-07

Palau J, Shouakar-Stash O, Hatijah Mortan S, Yu R, Rosell M, Marco-Urrea E, Freedman DL, Aravena R, Soler A, Hunkeler D (2017) Hydrogen Isotope Fractionation during the Biodegradation of 1,2Dichloroethane: Potential for Pathway Identification Using a Multi-element $(\mathrm{C}, \mathrm{Cl}$, and $\mathrm{H})$ Isotope Approach. Environ Sci Technol 51:10526-10535. https://doi.org/10.1021/acs.est.7b02906

Payne KA, Quezada CP, Fisher K, Dunstan MS, Collins FA, Sjuts H, Levy C, Hay S, Rigby SE, Leys D (2015) Reductive dehalogenase structure suggests a mechanism for B12-dependent dehalogenation. Nature 517:513-516. https://doi.org/10.1038/nature13901

Peng X, Huang X, Jing F, Zhang Z, Wei D, Jia X (2015) Study of novel pure culture HBCD-1, effectively degrading Hexabromocyclododecane, isolated from an anaerobic reactor. Bioresour Technol 185:218- 
Peng X, Wei D, Huang Q, Jia X (2018) Debromination of Hexabromocyclododecane by Anaerobic Consortium and Characterization of Functional Bacteria. Front Microbiol 9:1515. https://doi.org/10.3389/fmicb.2018.01515

Roosens L, Abdallah MA, Harrad S, Neels H, Covaci A (2009) Exposure to hexabromocyclododecanes (HBCDs) via dust ingestion, but not diet, correlates with concentrations in human serum: preliminary results. Environ Health Persp 117:1707-12. https://doi.org/10.1289/ehp.0900869

Roth, C., Gröning, J.A., Kaschabek, S.R., Schlömann, M., Sträter, N., 2013. Crystal structure and catalytic mechanism of chloromuconolactone dehalogenase ClcF from Rhodococcus opacus $1 \mathrm{CP}$. Mol. Microbiol. 88, 254-67. https://doi.org/10.1111/mmi.12182

Sellström U, Kierkegaard A, de Wit C, Jansson B (1998) Polybrominated diphenyl ethers and hexabromocyclododecane in sediment and fish from a Swedish River. Environ Toxicol Chem 17:10651072. https://doi.org/10.1002/etc.5620170612

Shah SB, Ali F, Huang L, Wang W, Xu P, Tang H (2018) Complete genome sequence of Bacillus sp. HBCDsjtu, an efficient HBCD-degrading bacterium. 3 Biotech 8:291. https://doi.org/10.1007/s13205-018-13268

Shah SB, Huang L, Hu H, Wang W, Ali F, Xu P, Tang H (2019) Characterization of environmentally friendly degradation of hexabromocyclododecane by a Bacillus strain HBCD-sjtu. Int Biodeter Biodegr 145:104794. https://doi.org/10.1016/j.ibiod.2019.104794

Stiborova H, Vrkoslavova J, Pulkrabova J, Poustka J, Hajslova J, Demnerova K (2015) Dynamics of brominated flame retardants removal in contaminated wastewater sewage sludge under anaerobic conditions. Sci Total Environ 533:439-45. https://doi.org/10.1016/j.scitotenv.2015.06.131

Suar M, Hauser A, Poiger T, Buser HR, Muller MD, Dogra C, Raina V, Holliger C, van der Meer JR, Lal R, Kohler HP (2005) Enantioselective transformation of alpha-hexachlorocyclohexane by the dehydrochlorinases LinA1 and LinA2 from the soil bacterium Sphingomonas paucimobilis B90A. Appl Environ Microbiol 71:8514-8. https://doi.org/10.1128/AEM.71.12.8514-8518.2005

van Hylckama Vlieg JE, Poelarends GJ, Mars AE, Janssen DB (2000) Detoxification of reactive intermediates during microbial metabolism of halogenated compounds. Curr Opin Microbiol 3:25762. https://doi.org/10.1016/S1369-5274(00)00086-2

Verma H, Kumar R, Oldach P, Sangwan N, Khurana JP, Gilbert JA, Lal R (2014) Comparative genomic analysis of nine Sphingobium strains: insights into their evolution and hexachlorocyclohexane $(\mathrm{HCH})$ degradation pathways. BMC Genomics 15:1014. https://doi.org/10.1186/1471-2164-15-1014 
Wang Y, Xin Y, Cao X, Xue S (2015) Enhancement of L-2-haloacid dehalogenase expression in Pseudomonas stutzeri DEH138 based on the different substrate specificity between dehalogenaseproducing bacteria and their dehalogenases. World J Microbiol Biotechnol 31: 669-

73. https://doi.org/10.1007/s11274-015-1817-2

Yamada T, Takahama Y, Yamada Y (2009) Isolation of Pseudomonas sp. strain HB01 which degrades the persistent brominated flame retardant gamma-hexabromocyclododecane. Biosci Biotechnol Biochem 73:1674-8. https://doi.org/10.1271/bbb.90104

Yano T, Yoshida N, Yu F, Wakamatsu M, Takagi H (2015) The glyoxylate shunt is essential for $\mathrm{CO}_{2}{ }^{-}$ requiring oligotrophic growth of Rhodococcus erythropolis N9T-4. Appl Microbiol Biot 99:562737. https://doi.org/10.1007/s00253-015-6500-x

Yasmin S, Whalen M (2018) Flame retardants, hexabromocyclododecane (HCBD) and tetrabromobisphenol a (TBBPA), alter secretion of tumor necrosis factor alpha (TNFalpha) from human immune cells. Arch Toxicol 92:1483-1494. https://doi.org/10.1007/s00204-018-2156-5

Yu F, Li YY, Wang H, Peng T, Wu YR, Hu Z (2021) Microbial debromination of hexabromocyclododecanes. Appl Microbiol Biotechnol 105:4535-4550. https://doi.org/10.1007/s00253-021-11095-3

Yu Y, Zhou D, Wu F (2015) Mechanism and products of the photolysis of hexabromocyclododecane in acetonitrile-water solutions under a UV-C lamp. Chem Eng J 281:892899. https://doi.org/10.1016/j.cej.2015.07.031

Zhang H, Yu T, Li J, Wang YR, Wang GL, Li F, Liu Y, Xiong MH, Ma YQ (2018a) Two dcm Gene Clusters Essential for the Degradation of Diclofop-methyl in a Microbial Consortium of Rhodococcus sp. JT-3 and Brevundimonas sp. JT-9. J Agric Food Chem 66:2217-12226. https://doi.org/10.1021/acs.jafc.8b05382

Zhang Y, Lu Y, Wang P, Li Q, Zhang M, Johnson AC (2018b) Transport of Hexabromocyclododecane (HBCD) into the soil, water and sediment from a large producer in China. Sci Total Environ 610-611:94100. https://doi.org/10.1016/j.scitotenv.2017.08.039

Zhong Y, Peng P, Yu Z, Deng H (2010) Effects of metals on the transformation of hexabromocyclododecane (HBCD) in solvents: implications for solvent-based recycling of brominated flame retardants. Chemosphere 81:72-8. https://doi.org/10.1016/j.chemosphere.2010.06.061

Zhong Y, Wang H, Yu Z, Geng X, Chen C, Li D, Zhu X, Zhen H, Huang W, Fennell DE, Young LY, Peng P (2018) Diastereoisomer-Specific Biotransformation of Hexabromocyclododecanes by a Mixed Culture Containing Dehalococcoides mccartyi Strain 195. Front Microbiol

9:1713. https://doi.org/10.3389/fmicb.2018.01713

\section{Figures}




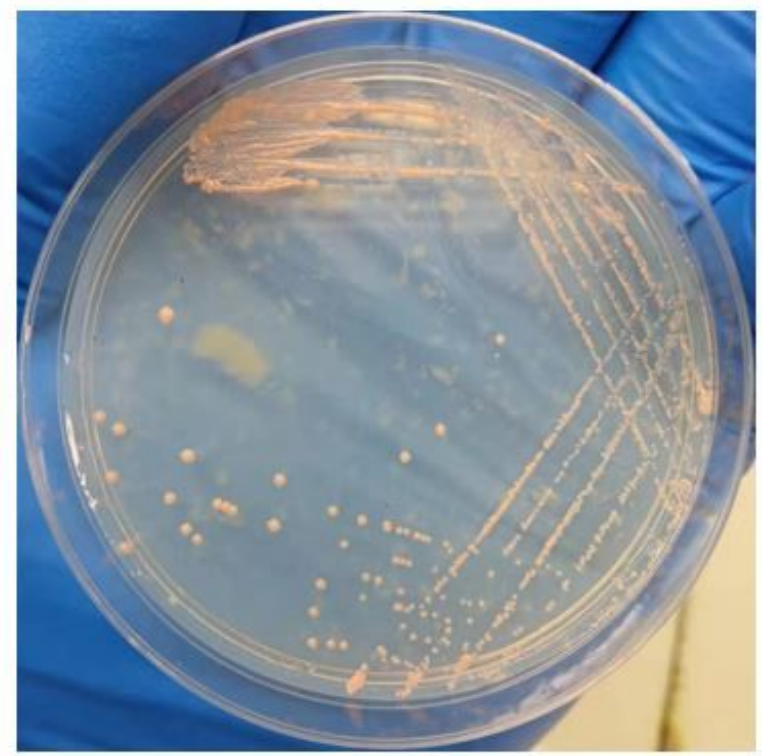

(a)

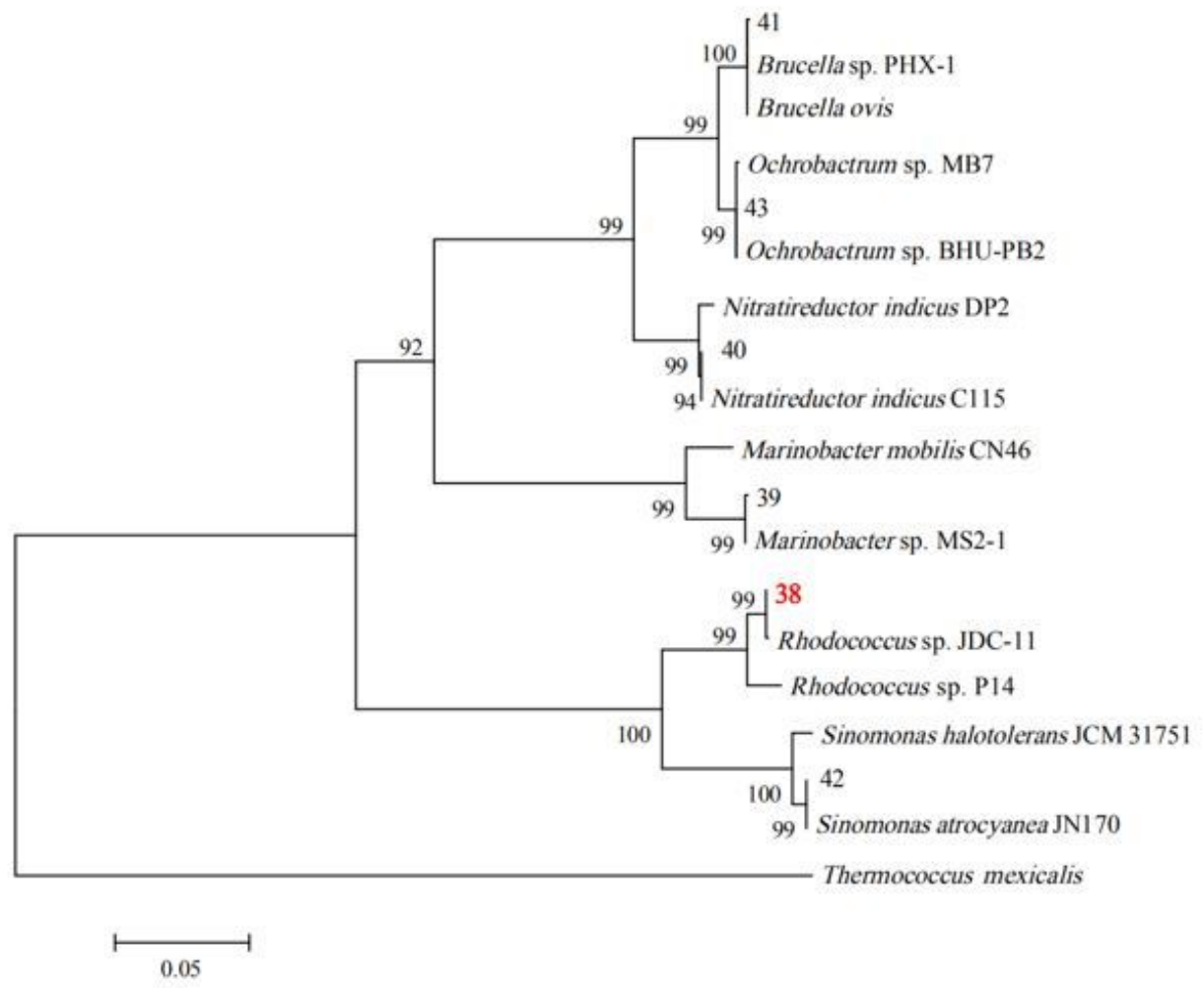

(b)

Figure 1

(a) The morphology of colony of strain stu-38. (b) The neighbor-joining tree of six isolated bacteria 


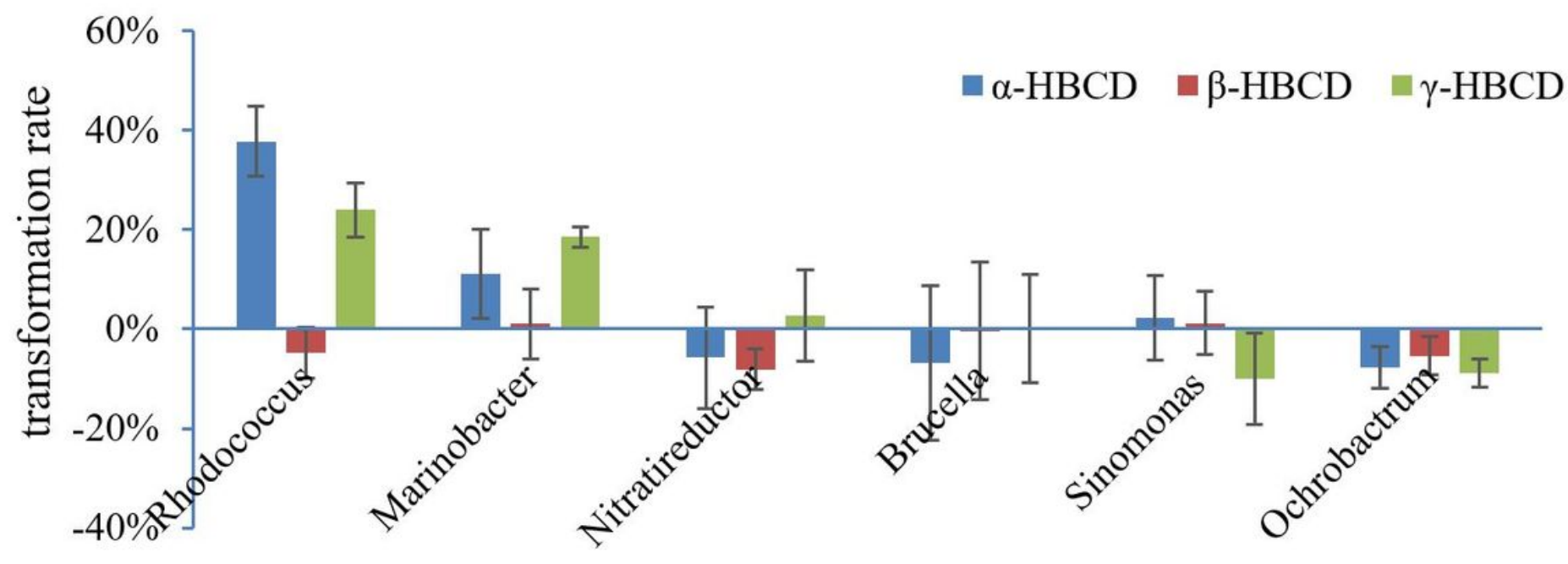

Figure 2

The HBCDs transforming rates of six isolated strains

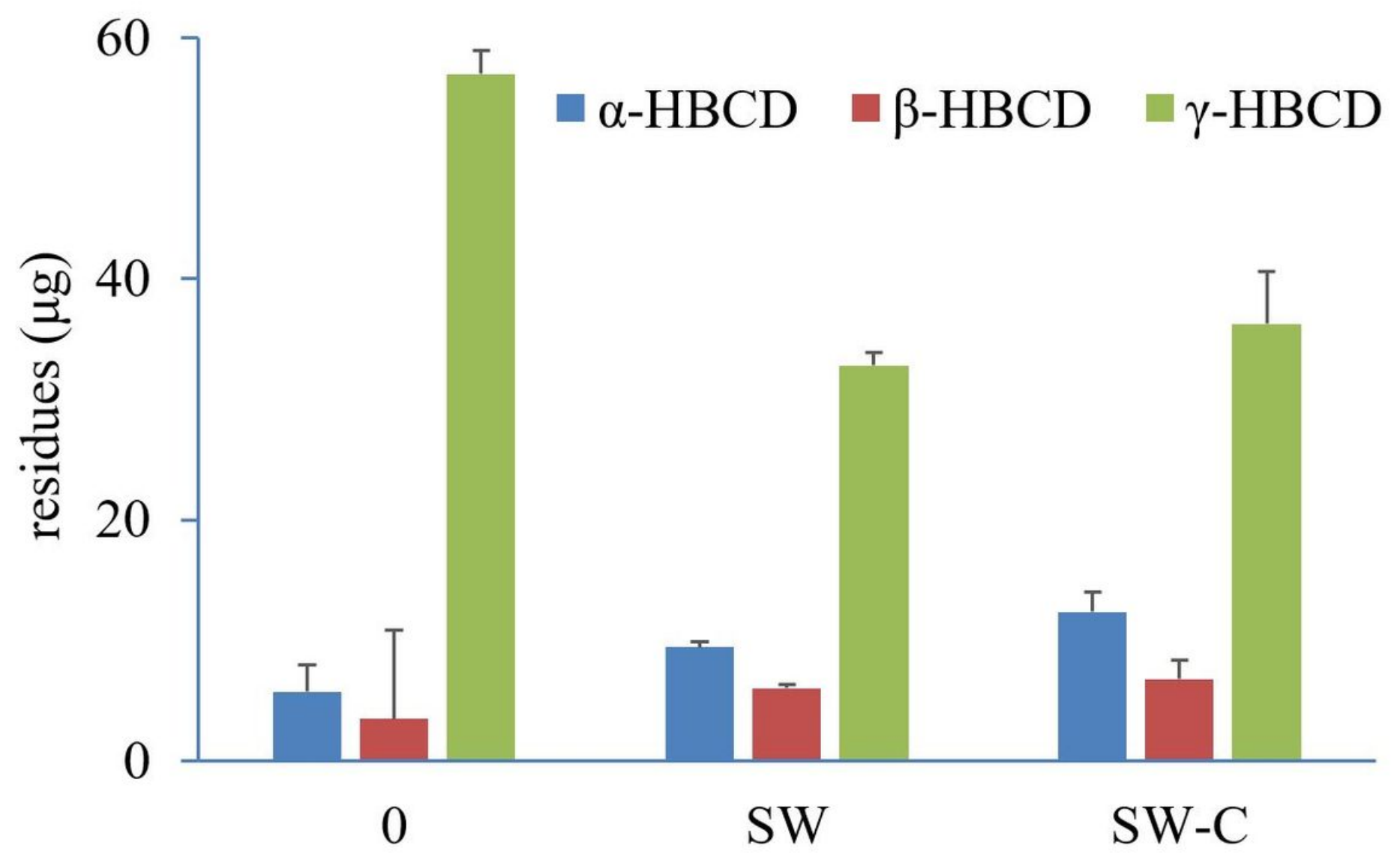

Figure 3

Residues of HBCDs in the SW and SW-C 


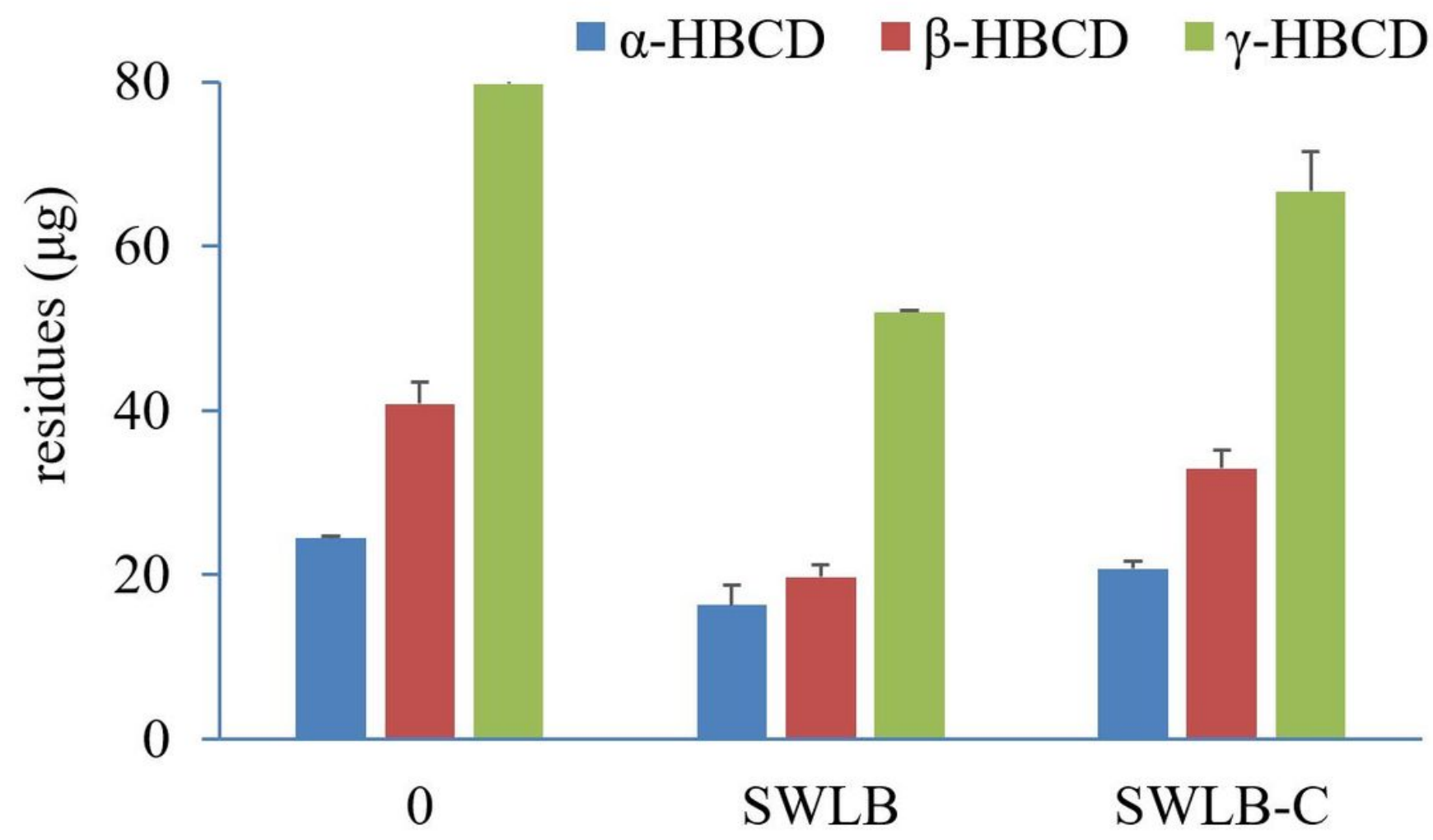

Figure 4

Residues of HBCDs in the SWLB and SWLB-C 


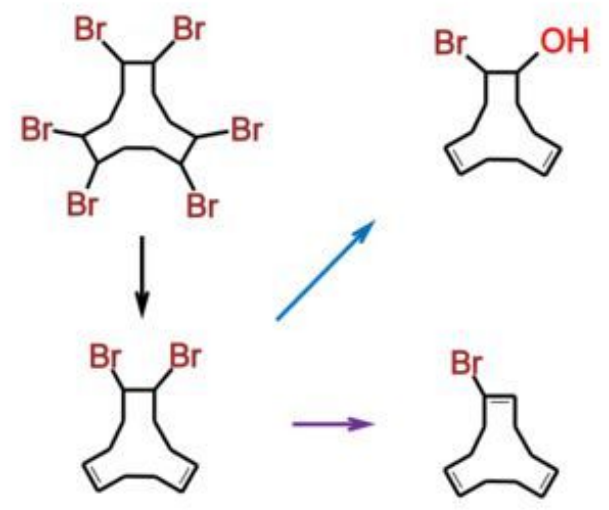

(a)<smiles>BrC(Br)CC(Br)CC(Br)C(Br)CC(Br)Br</smiles><smiles>OC1CCCCC1</smiles>
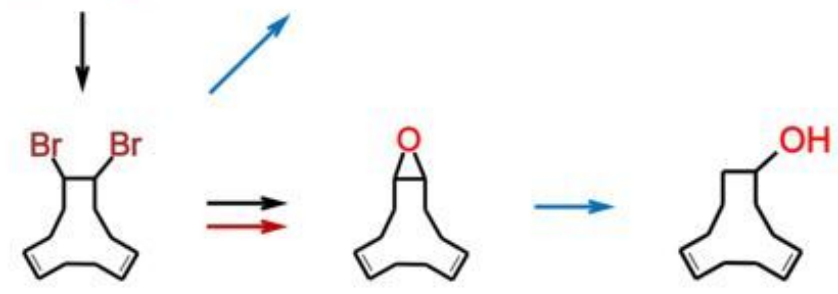

(b)<smiles>BrC1CC(Br)C(Br)CC(Br)C(Br)C1</smiles><smiles>OC1CCCCC1Br</smiles><smiles>[3H][3H]</smiles>

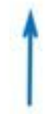<smiles>BrC1CCCCC1Br</smiles><smiles>OC1CCCCCCC1</smiles>

(c)

\section{Figure 5}

The putative transformation pathway of HBCDs by stu-38 in the (a) FW, (b) SW and (c) SWLB. Black arrow indicates the reductive debromination, blue arrow indicates hydrolytic debromination, the purple arrow shows the $\mathrm{HBr}$-elimination, red arrows represents oxidative reaction

\section{Supplementary Files}


This is a list of supplementary files associated with this preprint. Click to download.

- Graphicabstract.docx

- supplementarymaterialHBCDsR.spstu38.docx 